International Conference on Business Research

University of Moratuwa, Moratuwa, Sri Lanka

June 13, 2018, 10-18.

DOI: https://doi.org/10.31705/ICBR.2018.3

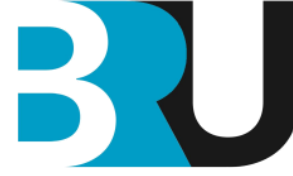

BUSINESS RESEARCH UNIT

FACULTY OF BUSINESS

UNIVERSITY OF MORATUWA

\title{
Business growth of a hospitality IT solutions provider: a success case of Intahub (Pvt) Ltd
}

\author{
Sashika Mendis*, Gayan Jayakody and Tilak Fonseka \\ Postgraduate Institute of Management, University of Sri Jayewardenepura, Sri \\ Lanka
}

The hospitality IT solutions industry of Sri Lanka can be considered as an oligopoly market, with few established Sri Lankan players and a couple of global and regional giants catering the high-end customers. Intahub (Private) Limited entered the market in 2015 with an innovative product, which was not offered by the Sri Lankan players. Within the three-year journey, the company has achieved a significant business growth, competing with quarter century old firms. The main purpose of the study was to explore the drivers that contributed to the business growth of Intahub. Business growth being the outcome of the case framework, four key drivers were identified contributing towards the business growth. The environmental moderator identified at Intahub was the competitive environment. Several secondary data sources were used in obtaining the preliminary information related to the case. This was followed by primary data gathering techniques, such as in-depth interviews and focus group discussions. Selection of employees covered both solution development staff and marketing staff, representing different levels of the organization. Collected qualitative data was analysed using the thematic analysis method. Entrepreneurial characteristics were identified as a key contributor, where the solid education background, compelling "entrepreneurial story", prior experience, and social networks of the owner have contributed towards the success case of Intahub. Human talent of the company has favourably contributed towards its success case, where competencies and commitment of employees have been more dominant. However, employee contribution has been less dominant at Intahub. Strategic alliances were identified as another key driver. Factors contributing towards a long-lasting relationship were identified as picking a good partner, equal sharing of benefits among the partners, and enhancing the trust by keeping their commitments. Value innovation through buyer value creation and cost elimination

*Corresponding author. Email: mahawattage@hotmail.com 
has immensely contributed towards the business growth of Intahub throughout the three-year period.

Key Words: business growth, value innovation, entrepreneurial drive, human talent, strategic alliances

\section{Introduction}

In this study, it was mainly expected to understand the success case of Intahub. Hence, the scope of the study was very much limited to the company, with least emphasis on its competitors and the industry. The process of becoming a successful company in the hospitality IT solutions industry through business growth was studied, in relation to Intahub. In this process, different characteristics of the company, its stakeholders and its environment were identified. The challenges faced by the company were investigated, while examining the strategies employed by the company in overcoming such challenges.

When reviewing the literature, links could be identified between the events and theories discussed in the literature. Competing in the existing markets, which are known as red oceans, do not add real value to the organizations. According to the Blue Ocean Strategy, a company must always look out for uncontested market spaces, which are known as blue oceans (Kim \& Mauborgne, 2005a). The Blue Ocean Strategy has been executed by Intahub at its initial stage by introducing an online channel manager to the Sri Lankan market. The value innovated by the company has immensely contributed towards its business growth. Benefits of moving in to strategic alliances were discussed, along with the factors contributing towards sustaining such alliances. Intahub's alliances for promoting its brand and for cross selling its products, have definitely helped the company in achieving its current success. Key entrepreneurial characteristics were related to the owner of Intahub, while highlighting the importance of having individuals with such characteristics in the initial teams. According to research, effective talent management is considered a tedious task for any organization. At the same time, it is vital to assess and protect the talent pool of the organization (Ulrich, 2007). Ulrich's talent formula, the talent trifecta, was reviewed, which Intahub can use on a continual basis in managing its talent pool.

When considering the past three years of Intahub, it was evident that its' business has been growing continuously from the inception. During the first half of this period, a moderate growth was visible, while the second half showing a rapid growth in the business. In March 2017, Intahub set its own goal of becoming the market leader in the hospitality IT solutions industry by March 2018. Within the first six months since setting this goal, the company has managed to double its customer base, indicating a solid business growth. The business growth of a company can be measured using many different yardsticks. Increase in revenue, profits, customer base, market share and employees over a period of time can be considered as few key measures of business growth. In relation to Intahub, the growth of the business was 
mainly discussed considering the increase in number of customers and number of employees over the three-year period. The key objective of this study was to explore the drivers that contributed to the success of Intahub. Figure 1 depicts the growth of customers and employees over the time period in concern. It also identifies the significant events which took place during this period, along with the key drivers which significantly contributed towards these significant events.

\section{Literature review}

The literature survey was extended to the probable contributory factors of business growth, which were value innovation, entrepreneurial drive, human talent, strategic alliances and competitive environment. Growth rate of an organization is strongly contributed by firm-specific, founder-specific, and external factors (Almus \& Nerlinger, 1999). It also identifies that large and mature firms have smaller growth rates, compared to small and young innovative as well as non-innovative firms. Entrepreneurial characteristics, employee competence and strategy making are significantly contributing towards the business growth of SME (Ratnayake, Menike \& Perera, 2013). Out of these contributory factors, entrepreneurial characteristics have been identified as having a strong relationship with business growth. Employee competence and strategy making have been identified as having a moderating effect on business growth. Further, the moderating effect of employee commitment and organizational culture were not proven, signifying a least impact on business growth. Business partnering with Taurus and Scienter Technologies, the two key local competitors, expedited the growth of Intahub.

Specific component variables of entrepreneurs' traits, skill, and motivation categories have significant impact on the venture growth. (Baum \& Locke, 2004) According to the opportunity recognition process, personal characteristics of an entrepreneur play a key role in identifying an opportunity gap in the market (Barringer \& Ireland, 2011). Though both environmental trends and entrepreneurial characteristics have been identified as key contributors towards opportunity recognition, the prominence given on environmental trends is comparatively lower. A firm's growth is not automatic (Barringer, Jones \& Neubaum, 2005). Growing a firm can be considered a management challenge, similar to any other managerial challenge faced by the entrepreneurs.

The negotiating position of employees in the workplace has been increasing over the past, creating an impact on the employment relationship and subsequently on employment policies and practices (Holland, Sheehan, \& Pyman, 2007). Hence, the organizations need to have higher emphasis on recruitment and selection, which is critical in managing the human talent. Effective talent management is considered a tedious task for any organization. (Ulrich, 2007) At the same time, it is vital to assess and protect the talent pool of the organization. 
ICBR 2018

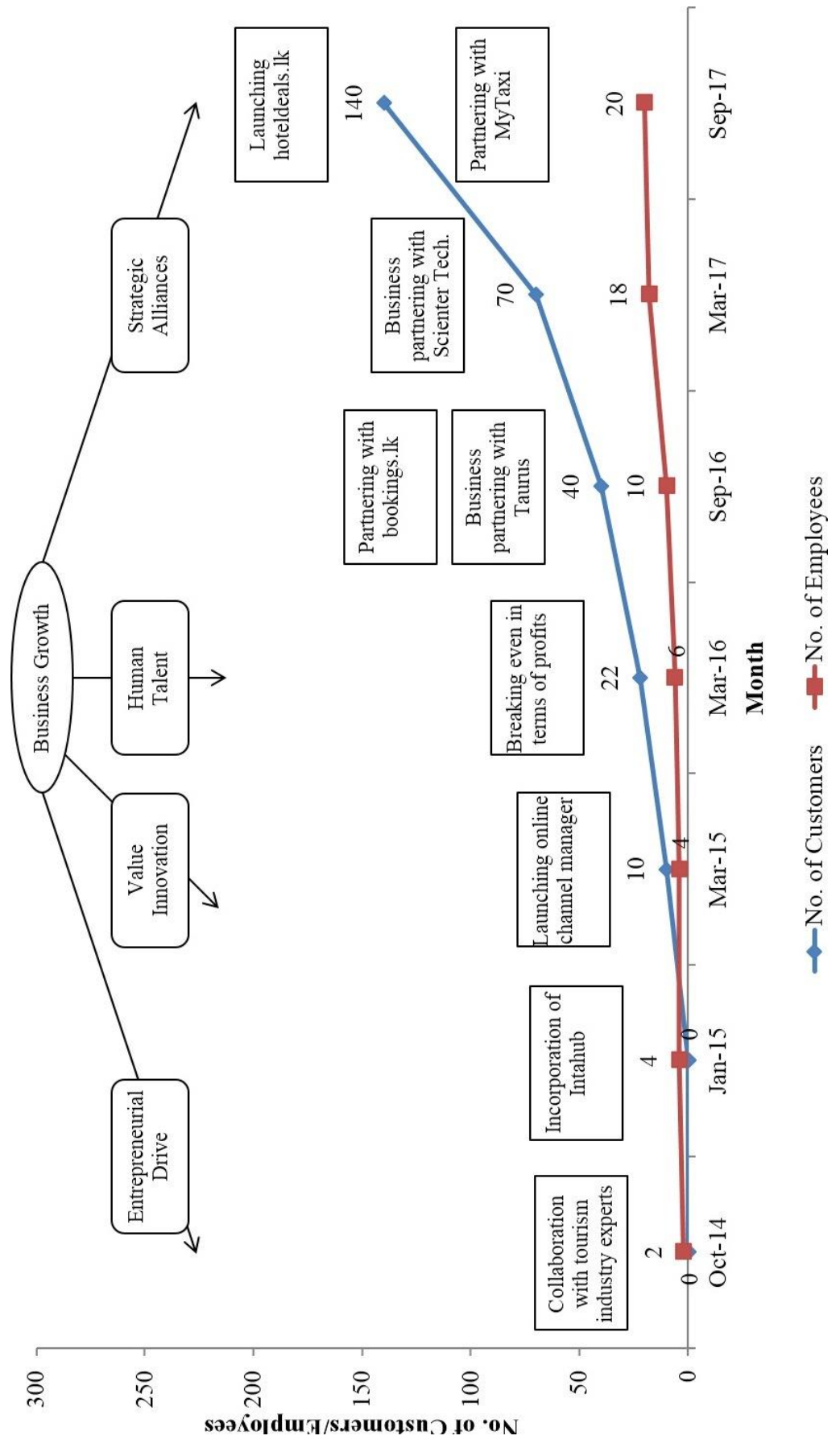

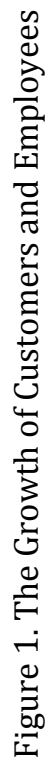


Organizations are having many benefits by entering in to strategic alliances. (Thompson, Peteraf, Gamble, \& Strickland III, 2012) Strategic alliances reduce the initial investment cost, since resources can be shared among the partners. Creating, developing, and maintaining a successful alliance is a truly challenging task. (Whipple \& Frankel, 2000) The study has been carried out to identify the key factors contributing towards successful long-term alliances.

According to the Blue Ocean Strategy, a company must always look out for uncontested market spaces, which are known as blue oceans. (Kim \& Mauborgne, 2005a) Competing in the existing markets, which are known as red oceans, do not add real value to the organizations. $86 \%$ of the businesses launched are mere line extensions in the existing markets. (Kim \& Mauborgne, $2005 \mathrm{~b}$ ) However, these $86 \%$ of the firms have contributed to only $62 \%$ of the total revenues and $39 \%$ of the total profits. The Blue Ocean Strategy needs not be applied only to new business ventures (Prematunga, 2009). Even the existing businesses can look at creating blue oceans in their current contexts.

\section{Methodology}

As it was important to gather historic data relating to the past three years, secondary data was the best source to understand the past performance of the company. The secondary data sources of Intahub were accessed in this regard, namely the company profiles, organizational charts, company website, YouTube ${ }^{\circledR}$, Facebook ${ }^{\circledR}$, and customer information.

Purpose specific primary data allowed the author in reaching the required information, being in line with the study objectives. The primary data instruments were used at Intahub in data gathering, namely the in-depth interviews, and focus group discussions. Ten in-depth interviews were carried out at Intahub, covering the owner and key employees. The owner was interviewed a couple of times during the initial stages of the study as well, for preliminary data gathering. Each of these semi structured interviews went up to one and a half hours, which gave the author a very clear understanding of the success case of Intahub. Selection of the employees covered both solution development staff and marketing staff. The employees from different levels of the organization were selected, in order to obtain a multidimensional view. Three focus group discussions were carried out at Intahub. Considering the size of the organization, each focus group was limited to four participants. One focus group consisted of the marketing staff, to get an understanding of the challenges faced and how they overcame such challenges. The other two focus groups consisted of senior staff and junior staff, in order to dig in to some of the points surfaced out during the interviews.

Primary data collected through in-depth interviews and focus group discussions was analysed, in order to arrive at meaningful information. Since the primary data collected was qualitative data, the thematic analysis method was followed in analysing the data (Braun \& Clarke, 2013). The steps used included transcribing interview data, reading and familiarization, coding, 
searching for themes and relationships between themes, reviewing the patterns, and writing. Table 1 identifies the themes related to the coding, and the relationships between the themes.

\section{Analysis, results and discussion}

Four key drivers were identified in the case study, which have directly contributed to the business growth of Intahub, resulting in increase of revenue, profits, customer base, market share and employees.

Table 1. Identification of themes and their relationships

\begin{tabular}{l|l|l}
\hline Codes & Themes & Related to \\
\hline $\begin{array}{l}\text { Blue ocean/Buyer value/Market gap/New } \\
\text { markets/Uncontested market/White label } \\
\text { product }\end{array}$ & \multirow{2}{*}{ Value Innovation } & \\
\cline { 1 - 2 } $\begin{array}{l}\text { Entrepreneurial background/Entrepreneurial } \\
\text { characteristics/Prior experience of }\end{array}$ & \multirow{2}{*}{$\begin{array}{l}\text { Entrepreneurial } \\
\text { entrepreneur/Social network }\end{array}$} & \\
\cline { 1 - 2 } $\begin{array}{l}\text { Commitment/Competence/Complete product } \\
\text { basket/Integration for customer/New }\end{array}$ & & \\
$\begin{array}{l}\text { technology/Prior experience of } \\
\text { employees/Product development/Product } \\
\text { quality/Switching cost of }\end{array}$ & \multirow{2}{*}{ Human Talent } \\
$\begin{array}{l}\text { customer/Teamwork/Technology } \\
\text { development/Top talent }\end{array}$ & \\
\cline { 1 - 2 } $\begin{array}{l}\text { Business partnering/Cross selling/Industry } \\
\text { experts/Market leadership/Partnering for } \\
\text { branding/Partnering with } \\
\text { competitors/Partnering with customer }\end{array}$ & \\
$\begin{array}{l}\text { hotels/Partnerships/Strategic } \\
\text { alliance/Trust/Win-win with } \\
\text { competitors/Win-win with customers/Win- } \\
\text { win with partners }\end{array}$ & & \\
\hline
\end{tabular}

As described in research, entrepreneurial drive has been having a direct impact on the business growth of Intahub too (Barringer et al., 2005). The entrepreneurial drive could be identified in relation to the different characteristics which were visible from the owner of Intahub. His strong education background has helped the company with its growth. The compelling "entrepreneurial story" behind the owner would have helped him with the vital decision making required at the early stages of the company. His prior experience in the same industry immensely contributed towards the business growth of Intahub. The social networks of the owner supported him whenever he was to make alliances for the benefit of the company.

Human talent of Intahub too has favourably contributed towards its success case (Ulrich, 2007). The human talent of the company was evaluated in relation to the talent trifecta, which comprises of competence, commitment, 
and contribution. As identified in prior research, competencies of the employees have directly contributed to the business growth of Intahub. Though research has not been giving prominence to employee commitment as a direct contributory factor, the commitment of Intahub employees have helped the organization in reaching where it is today. With the fulfilment of their personal needs, the employees of Intahub have been contributing to the company to achieve its goals.

Strategy making identified in literature was also a direct contributory factor to the growth of Intahub (Whipple \& Frankel, 2000). At Intahub, strategy making could be identified as strategic alliances, since the company was insisting on business partnering with different parties in taking the company to its next level. Factors affecting strong strategic alliances were evaluated in relation to Intahub. Picking a good partner has helped the company in maintaining long-term relationships in driving the business forward. Benefit for both parties has been another key factor for the strong alliances at Intahub. Furthermore, Intahub keeps its commitments, so that the partners too would be compelled to maintain the trust.

Value innovation has contributed towards the company's business growth throughout the three-year period (Kim \& Mauborgne, 2005a). Value innovation was illustrated using its two key factors, which are buyer value and cost. Intahub created buyer value through its online channel manager, where the customer was offered higher accuracy and seamless integration. The cost of the customer was reduced through time saving and evading customer dissatisfaction.

Considering the key drivers, environmental moderators and outcomes identified above, the following case framework in Figure 2 was developed in narrating the success case of Intahub.

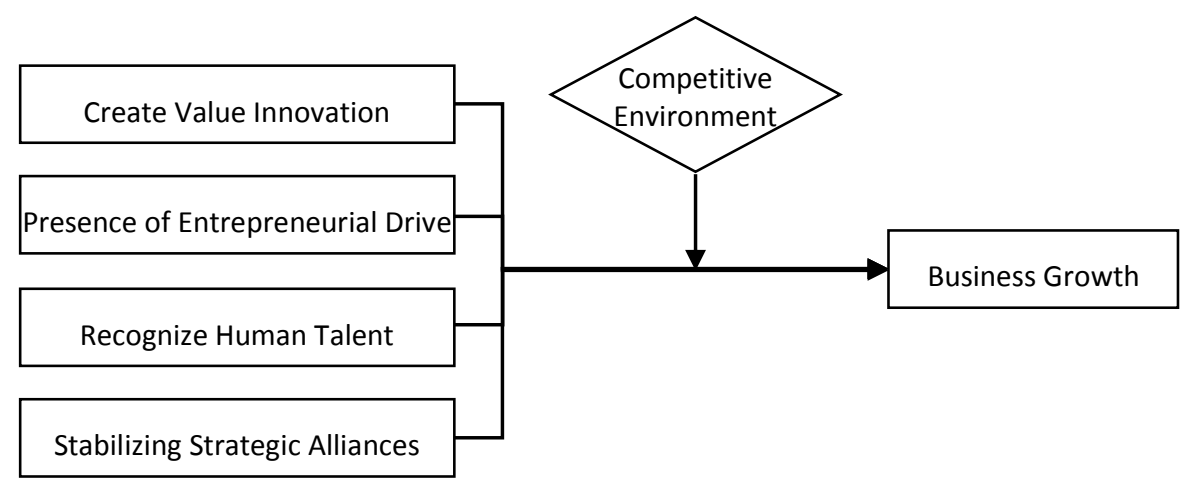

Figure 2. Case framework

\section{Conclusion and implications}

Entrepreneurial characteristics were identified as a key contributor, where the solid education background and the compelling "entrepreneurial story" of the owner have helped the company during its initial stages. The prior 
experience and social networks of the owner too have contributed towards the success case of Intahub. Human talent of the company was discussed under three main areas, namely the employee competence, commitment and contribution.

Strategic alliances were identified as another key driver. Factors contributing towards a long-lasting relationship were identified, mainly picking a good partner. Benefits of the alliance should be equally shared among the partners, while enhancing the trust by keeping their commitments. Value innovation, though not recognized as a success factor in literature, has immensely contributed towards the business growth of Intahub.

Prior research carried out on hospitality IT solutions industry were found scarce. In this context, the author had to refer to research on IT related industries carried out mainly outside of Sri Lanka. Furthermore, to compensate this space, research carried out on similar or related service industries of Sri Lanka were referred to being a private limited liability company. Disclosure of revenue and profits of Intahub in a public domain was a concern, which could give an undue advantage to its competitors in an oligopoly market. Hence, the study was carried out without disclosing any financial information of the company, which was a limitation of this study.

Since the main focus of this study was on how Intahub succeeded as a hospitality IT solutions provider, the study was not extended to examine the company's competitors in detail. Intahub being in an oligopoly market where the competitors' information was also not freely available in public domains, made the author limiting the boundaries of this study, while identifying it as a future research opportunity.

\section{Acknowledgement}

Mr. Dimuth Dunusinghe, Managing Director, and the staff of Intahub (Private) Limited for sharing their information to make this study a reality.

\section{References}

Almus, M., \& Nerlinger, E. A. (1999). Growth of new technology-based firms: which factors matter. Small Business Economics, 13, 141-154.

Barringer, B. R., Jones, F. F., \& Neubaum, D. O. (2005). A quantitative content analysis of the characteristics of rapid-growth firms and their founders. Journal of Business Venturing, 20, 663-687.

Barringer, B. R., \& Ireland, R. D. (2011). Entrepreneurship: successfully Launching New Ventures. $3^{\text {rd }}$ ed. Pearson Prentice Hall: New Delhi.

Baum, J. R., \& Locke, E. A. (2004). The relationship of entrepreneurial traits, skill, and motivation to subsequent venture growth. Journal of Applied Psychology, 89(4), 587-598.

Braun, V., \& Clarke, V. (2013). Successful qualitative research: a practical guide for beginners. $1^{\text {st }}$ ed. Sage: London.

Holland, P., Sheehan, C., \& Pyman, A. (2007). Attracting and retaining talent: exploring human resources development trends in Australia. Human Resource Development International, 10(3), 247-262. 
Kim, W. C., \& Mauborgne, R. (2005a). Blue Ocean strategy: how to create uncontested market space and make the competition irrelevant. $1^{\text {st }}$ ed. Harvard Business School Press: Boston.

Kim, W. C., \& Mauborgne, R. (2005b). Value innovation: a leap into the Blue Ocean. Journal of Business Strategy, 26(4), 22-28.

Prematunga, W. D. L. (2009). A Blue Ocean branding strategy: the case of Mlesna. Sri Lankan Journal of Management, 14(3), 64-81.

Ratnayake, R. M. T. H., Menike, E. D. T. M. N. D., \& Perera, T. (2013). Factors affecting growth of SMEs in tourism industry in Sri Lanka. Sri Lankan Journal of Management, $18(3$ \& 4), 113-137.

Thompson, A. A., Peteraf, M. A., Gamble, J. E., \& Strickland III, A. J. (2012). Crafting and Executing Strategy: The Quest for Competitive Advantage: Concepts and Cases. 18 ${ }^{\text {th }}$ ed. McGraw Hill: New York.

Ulrich, D. (2007). The talent trifecta. Workforce Management, 86(15), 32-33.

Whipple, J. M., \& Frankel, R. (2000). Strategic alliance success factors. Journal of Supply Chain Management, 36(3), 21-28. 